\section{Clinical benefit of vedolizumab on articular manifestations in patients with active spondyloarthritis associated with inflammatory bowel disease}

Vedolizumab (VDZ) is a new biological agent which was recently approved for the treatment of inflammatory bowel disease (IBD) ${ }^{1}$ following the good clinical responses reported by clinical trials for both Crohn's disease ${ }^{2}$ and ulcerative colitis. ${ }^{3}$ However, the effects of VDZ on extraintestinal manifestations

\begin{tabular}{|c|c|}
\hline Variable & $n=53$ \\
\hline Age (years), mean $\pm S D$ & $51.5 \pm 15.7$ \\
\hline Male gender, n (\%) & $28(52.8)$ \\
\hline \multicolumn{2}{|l|}{ Smokers, n (\%) } \\
\hline Never & $50(94.3)$ \\
\hline Current & $2(3.8)$ \\
\hline Ex & $1(1.9)$ \\
\hline \multicolumn{2}{|l|}{ Type of disease, n (\%) } \\
\hline Crohn's disease & $34(64.2)$ \\
\hline Ulcerative colitis & $19(35.8)$ \\
\hline Duration of disease (years), mean $\pm S D$ & $13.6 \pm 9.4$ \\
\hline \multicolumn{2}{|l|}{ Localisation of the disease, $\mathrm{n}(\%)$} \\
\hline \multicolumn{2}{|l|}{ Crohn's disease } \\
\hline Ileal & $3(8.8)$ \\
\hline Ileocolic & $26(76.5)$ \\
\hline Colic & $4(11.8)$ \\
\hline Upper gastrointestinal tract* & $1(2.9)$ \\
\hline Perianal disease & $7(20.6)$ \\
\hline \multicolumn{2}{|l|}{ Ulcerative colitis } \\
\hline Proctitis & $0(0.0)$ \\
\hline Left-sided & $6(31.6)$ \\
\hline Extensive & $13(68.4)$ \\
\hline \multicolumn{2}{|l|}{ Behaviour (Crohn's disease), n (\%) } \\
\hline Inflammatory & $16(47.1)$ \\
\hline Stricturing & $17(50.0)$ \\
\hline Fistulising & $1(2.9)$ \\
\hline Previous resections (Crohn's disease), n (\%) & $21(61.8)$ \\
\hline \multicolumn{2}{|l|}{ Previous biological treatments } \\
\hline Yes & $43(81.1)$ \\
\hline No (naïve to biologics) & $10(18.9)$ \\
\hline Steroid-dependent, n (\%) & $51(96.2)$ \\
\hline \multicolumn{2}{|l|}{ IBD-associated SpA } \\
\hline No history & $31(58.5)$ \\
\hline History (inactive at initiation of VDZ) & $8(15.1)$ \\
\hline Active at initiation of VDZ & $14(26.4)$ \\
\hline Peripheral arthropathy & $12(85.7)$ \\
\hline Axial and peripheral arthropathy & $2(14.3)$ \\
\hline \multicolumn{2}{|c|}{ Clinical benefit on SpA following initiation of VDZ $(n=14)$} \\
\hline No clinical benefit & $8 / 14(57.1)$ \\
\hline Improvement & $6 / 14(42.9)$ \\
\hline New onset/exacerbation of SpA induced by VDZ & 0 \\
\hline
\end{tabular}

*In addition to an ileocolic localisation.

IBD, inflammatory bowel disease; SpA, spondyloarthritis; VDZ, vedolizumab. were not reported in these trials, and the 'real life' experience is still limited. On these premises, we read with interest the recent work by Varkas et $a l^{4}$ reporting a series of five patients with IBD who were treated with VDZ and promptly developed new onset or exacerbation of spondyloarthritis $(\mathrm{SpA})$, irrespective of the response to treatment on intestinal symptoms. Although the hypotheses proposed by the authors to explain such events sound reasonable, we would like to report our different preliminary results on the effect of VDZ on IBD-associated SpA. From June to December 2016, a treatment with VDZ was started in 53 patients. Data were collected prospectively. Patient characteristics and main results are shown in table 1 . Notably, $81.1 \%$ of patients had been previously treated with at least one TNF- $\alpha$ inhibitor, and almost all (96.2\%) were steroid dependent. Overall, 36 out of 53 patients $(67.9 \%)$ completed the induction phase at last observation, and the mean follow-up of the entire cohort was $2.6 \pm 1.6$ months. Eight (15.1\%) patients had a history of IBD-associated SpA but were inactive at the time of initiation of VDZ, whereas $14(26.4 \%)$ had active SpA when VDZ was started. First, no case of induction or flare of arthritis and/or sacroiliitis was reported among the entire cohort, including the patients without a prior SpA diagnosis. Second, 6 out of the 14 patients with active SpA (46.2\%)-all complaining of peripheral arthropathy-experienced a sharp clinical benefit after the initiation of VDZ. About gut inflammation of these six patients, three of them were in clinical remission after 6 and 12 weeks of therapy, two were in remission after 6 weeks (they have not reached week 12 yet) and one patient did not experience any response on intestinal symptoms after 14 weeks of treatment. As a consequence, our preliminary prospective data indicate a potential benefit of VDZ on IBD-associated SpA. Even if we do not reject the possibility that VDZ may induce new onset or exacerbation of arthritis and/or sacroiliitis, the previous demonstration of $\alpha 4 \beta 7$ in the joint ${ }^{5}{ }^{6}$ and the recent evidence of the upregulation of mucosal vascular address in cell adhesion molecule (MadCAM-1) in the high endothelial venules of bone marrow in patients with active axial $\mathrm{SpA}^{7}$ seem to strengthen the hypothesis of a beneficial rather than a paradoxical effect of $\alpha 4 \beta 7$ blockade on articular manifestations of IBD. Obviously, more details about the molecular mechanisms underlying the $\alpha 4 \beta 7$ blockade in the joints are required, and large cohort studies are needed to provide more evidence on these preliminary findings.

Ambrogio Orlando, ${ }^{1}$ Rosalba Orlando, ${ }^{1}$ Francesco Ciccia, ${ }^{2}$ Sara Renna, ${ }^{1}$ Aroldo Rizzo, ${ }^{3}$ Mario Cottone, ${ }^{1}$ Fabio Salvatore Macaluso ${ }^{1}$

'Division of Internal Medicine, "Villa Sofia-Cervello" Hospital, Palermo, Italy ${ }^{2}$ Di.Bi.M.I.S., Section of Rheumatology, University of Palermo, Palermo, Italy 3Department of Pathology, "Villa Sofia-Cervello" Hospital, Palermo, Italy

Correspondence to Dr Ambrogio Orlando, Division of Internal Medicine, "Villa Sofia-V. Cervello" Hospital, Palermo 90146, Italy; ambrogiorlando@gmail.com

Competing interests FSM: lecture grant from MSD. SR: served as an advisory board member for AbbVie and MSD, and received lecture grants from AbbVie, MSD, Takeda Pharmaceuticals, Zambon. AO: served as an advisory board member for AbbVie, MSD, Takeda Pharmaceuticals; received lecture grants from AbbVie, MSD, Takeda Pharmaceuticals, Sofar, Chiesi. MC: received financial support for the organisation of a second-level master degree in inflammatory bowel disease from AbbVie, MSD, Takeda Pharmaceuticals and Sofar.

Provenance and peer review Not commissioned; internally peer reviewed. 
To cite Orlando A, Orlando R, Ciccia F, et al. Ann Rheum Dis 2017;76:e31.

Received 21 December 2016

Revised 27 December 2016

Accepted 28 December 2016

Published Online First 17 January 2017

\section{Linked}

http://dx.doi.org/10.1136/annrheumdis-2016-210045

Ann Rheum Dis 2017;76:e31. doi:10.1136/annrheumdis-2016-211011

\section{REFERENCES}

1 Armuzzi A, Gionchetti P, Daperno M, et al. Expert consensus paper on the use of Vedolizumab for the management of patients with moderate-to-severe Inflammatory Bowel Disease. Dig Liver Dis 2016;48:360-70.

2 Sandborn WJ, Feagan BG, Rutgeerts $\mathrm{P}$, et al. Vedolizumab as induction and maintenance therapy for Crohn's disease. N Engl J Med 2013;369:711-21.
3 Feagan $B G$, Rutgeerts $P$, Sands $B E$, et al. Vedolizumab as induction and maintenance therapy for ulcerative colitis. N Engl J Med 2013;369:699-710.

4 Varkas G, Thevissen K, De Brabanter G, et al. An induction or flare of arthritis and/or sacroilitis by vedolizumab in inflammatory bowel disease: a case series. Ann Rheum Dis 2017;76:878-81.

5 Salmi M, Jalkanen S. Endothelial ligands and homing of mucosal leukocytes in extraintestinal manifestations of IBD. Inflamm Bowel Dis 1998;4:149-56.

6 Salmi M, Jalkanen S. Human leukocyte subpopulations from inflamed gut bind to joint vasculature using distinct sets of adhesion molecules. I Immunol 2001;166:4650-7.

7 Ciccia F, Guggino G, Rizzo A, et al. Type 3 innate lymphoid cells producing IL-17 and IL-22 are expanded in the gut, in the peripheral blood, synovial fluid and bone marrow of patients with ankylosing spondylitis. Ann Rheum Dis 2015;74:1739-47. 